\title{
Islamic Spirituality Movement and Its Implications on Social and Political Ethics in Indonesia
}

\author{
DALMERI* \& RATONO ${ }^{1}$
}

\begin{abstract}
In the nineteenth century, Islamic religious movements fell into three groups: First, those advocating salvation through revivalism as exemplified by Wahhabism; Second, salvation through the prophecy of divinely-sent leader (or guide) as seen in the case of Mahdism; and third, salvation through ecstasy and loss of self-volition, such as in the Sufi Shaykh (charismatic leader), characteristic of the tariqa revival. This article explains about the attitudes of reformers towards Sufism varied from the hostility of Muhammad ibn 'Abd al-Wahhab who was against bid'a; the 'Salafi' movement, i.e Muhammad 'Abduh and Rashid Rida, who were against Sufism but tolerated the ethical teachings of al-Ghazali; and Mustafa Kemal in Turkey who banned Sufi orders outright in 1925. In recent Indonesia milieu, some prominent figures have shown their interest in Sufism, but certain Muslim organizations or institutions to some extent are against it such as Hizbut Tahrir Indonesia, Sabili Magazine, Salafy Journal, Muhammadiyyah, and Persatuan Islam.
\end{abstract}

Keywords: Indonesia, Salafism, spirituality, Sufi order, Sufism, tariqah, Wahhabism

Islam, from its arrival in Indonesia in the thirteenth century (or the seventh century according to some opinions) was characterized by mysticism, or Sufism as it is known in Islam. It certainly received a warm welcome from the people there, for it appears from what we know that the spread of Islam throughout the archipelago was made possible by the great and remarkable efforts of Sufi preachers. In addition, there are much evidences of the existence of various Sufi orders as well as reports of the activities of the Nine Saints (walisongo) to disseminate Islam in Java at the beginning of the fifteenth century. Even Marco Polo found that Islam had already been established in Sumatra in 1292 (Stoddart 2012: 42). Ibn Battuta in some later years discovered that there had already long been an Islamic kingdom in Samudra when he arrived in 1346 (Dunn 2012: 257).

In Indonesia the type of approach adopted by Sufis has attracted people to Islam, which has found the soil there fertile to its growth. However, the progress of Islamic mysticism has faced difficulties in recent decades due to the distractions of worldly life, to say nothing of the influence of ideas of reform and perhaps also secularization. This article will discuss the development of Islamic spirituality in Indonesia by first observing in brief the position of Sufism in Islamic teachings, its objectives and its part in the current Islamic religious movements, as well its social, cultural, educational and political roles and ethics in Islamic society. It also looks upon its challenge and future in Indonesia as well as the progress achieved until now. Furthermore, this article will discuss the example of one particular Sufi order that still plays an important role in Indonesia, namely the Tariqa Qadiriyya wa Naqshbandiyya in west Java. In

\footnotetext{
1 Dalmeri*(Corresponding author), Ph.D. candidate at Graduate Studies Program at Universitas Ibn Khaldun Bogor, Jl. K.H. Sholeh Iskandar Km. 2, BOGOR 16162, Indonesia, email: dalmeri300@gmail.com; Ratono, Ph.D., Rector of Sekolah Tinggi Agama Islam, Perguruan Tinggi Da'wah Islam Indonesia (STAIPTDII), Jalan Tawes, No. 21-22, Tanjung Priok, JAKARTA UTARA 14310, Indonesia, email: staipthawalib@yahoo.com.
} 
addition, considering the current religious climate in the country, we may perhaps draw some conclusions as to prospects for Sufism in Indonesia.

Some Western scholars have claimed that the origins of Sufism are to be found in the Quran and the Sunna, but they express themselves with numerous reservations, and suggest that in any event subsequent events took Sufism far from its primitive roots (Arberry 2008). In the Islamic world itself, various misconceptions of Sufism have also gained popularity in recent years. As for the Arab world, the view of Sufism as "a harmful and repugnant excrescence" on the body of Islam (Geoffroy 2010: 21), as it is regarded by the Wahhabis and the Salafiyya, continue to exercise its influence. The existence of Sufi orders throughout the Islamic world until the present time however, serves as a witness to the popularity of Sufism. Its historical role, during more than five centuries of the Islamic era, indicates an organic relationship with the social, spiritual and intellectual life of the whole Muslim community, assuring it a large measure of unity, continuity and vitality (Gorman 2010: 71).

Sufism, since its growth in the central Islamic lands in the eighth century until its golden age in the thirteenth, has been characterized by individual interpretations such as those of Hasan al-Basri, Rabi'ah al-Adawiyah, which later grew into tariqas which had their own versions of dhikr, bai'a, etc. However, the tariqas are like lines which extend from the circumference of a circle to the center. These lines are numerous; however, they all will end in the center -imagine the wheel of the bicycle. The center itself is the Quran al-Karim and the Sunna al-Sahiha. The tariqa and haqiqa unite to designate them. Hence, Sufism is not a separate school (madhhab) in terms of Islamic law; it is a path or a way which brings people to absolute truth, the tawhid.

\section{The Roles of Sufism in Indonesian as Ethics Society}

In the history of Islamic thought, there have been two tendencies in the observation of religious belief: first, the tendency to observe outward rules (shari'a); and second, the tendency to observe inner rules. There has been a long dispute concerning this matter, marked by mutual accusations of deviation from the faith and going astray; one thinker in particular however, alGhazali, was successful in integrating shari'a and tariqa. The principle of balance (tawazun) that is mentioned in the Quran (Quran, Al-Rahman, 55:7-8) should be maintained; any deviation from this principle will result in sin, for this goes against the rules which govern nature. If human beings may be said to be microcosms then they must observe the principle of balance in everything, including their spiritual life (see Quran, Al-Ahzab 39:62). The Prophet Muhammad has provided us with an example, followed by his companions, and then later followed by the Sufis.

The universality of the Quran is reflected in the fact that it contains only 500 verses which have absolute legal force; the rest of the verses need to be interpreted according to various details of situation and time. Since human beings tend to interpret things differently, various interpretations therefore exist and one might choose a certain interpretation that suits the occasion. Hence the interpretation of Islam can be applied and employed in any place and any time. In another words, the basic Islamic teachings are completely universal while their interpretations and implementations is subject to local values.

The aim of Sufism is to bring oneself as near as possible to God, even to unite with Him (ittihad). Since God is immaterial and holy, the only element of a human being that could approach Him is the soul, hence the human soul should be pure (Rohaimi et. al., 2015: 62). Purifying the soul (heart) is accomplished through worship; to be near to God, a Sufi should follow the ways or paths (turuq), which is a long and difficult process consisting of stages (maqamat) as well as certain conditions (ahwal). As in philosophy, Sufism discusses the basic principles, but unlike the former, which uses reason as a tool, Sufism utilizes the sense of feeling which is in the heart (qalb) as a means to seek God. 
Ibn Taymiya believed that tasawwuf (Sufism) constitutes a type of ijtihad towards Allah. He found references to dhikr (remembrance of God) in the Quran (e.g. Quran, Ali Imran 3:191, al-Ra'd 13:28, and al-Hasyr 59:19). The dhikr by Sufis in his day consisted in reciting Allah (lafz al-Jalala), whereas the dhikr recommended by Ibn Taymiyya, meant reciting La ilaha illa Allah; dhikr that consists in reciting "a single name," or ism mufrad, is not recommended (Muhammad Ali 2011: 140).

The teachings of tariqas which integrated well with the shari'a were admitted as mu'tabara (legitimate), while those which did not integrate well were regarded as ghayr mu'tabara. In the Indonesian case, we may refer to a large organization which was founded by the Nahdlatul 'Ulama' (NU), the central board of Jam'iyya Ahli Tariqa Mu'tabara which has established its branches through out Indonesia. At their national conference in Semarang in 1981, forty-five different Sufi orders were accepted as members and considered as providing a link to the Prophet Muhammad, peace be upon him (Dhofier 1985: 143-5).

In Indonesia, at first, the followers of tariqas were residents of the palace; later, however, the common people joined in greater numbers. Tariqas were viewed as a source of spiritual power at the same time as legitimating and empowering the position of the king. It is understandable however that the kings should have been reluctant to let the people encouraging people to have access to the same supernatural power (Bruinessen 1994: 17). Prior to the 18th century, many different tariqas attracted followers from all over Indonesia. People who came back from Mecca and Medina disseminated the Shattariyya order, which was sometimes integrated with the Naqshbandiyya or Khalwatiyya.

Indonesian Muslims were by no means homogeneous, yet while the community was culturally diverse it was unified at the same time. The main cause of a person's attachment to a Sufi order was usually the family link, and what kept him or her there were the spiritual, social, and economic benefits derived from that relationship. You were, so to speak, born a Muslim, a secularist, or a Shadhili; you were associated with your local community. The social significance of the orders was many sided but the religious significance was primary. It cannot be denied that to some extent Sufi organization was fully blended with the saint-cult: exploiting it, in fact, represented the religion of the ordinary people. Participation in its ritual ministered to the individual's need to oppose or transcend society, raising him or her temporarily into timeless supernatural experience.

The social role of the Sufi orders, though secondary to the religious one, was so important that no study on Islamic society, and particularly that of Indonesia, ought to ignore them. In traditional life, religion was the synthesis of human activity. The Sufi orders, binding together individuals with a supernatural bond, were themselves a social power. Orders came to be associated in various ways with different strata of society. They were organizations for mutual help, and a venerated shaykh could voice the people's grievances and condemn tyranny and oppression. They assisted the poor, and ministered to the sick and travelers.

\section{Cultural, Political and Educational Role}

The importance of Sufism in the culture of the Muslim lands is evident. The loss to Islamic thought and poetry, supposing the absence of Sufism, can hardly be contemplated. It inspired a vast and rich tradition of poetry and music, not merely in educated and sophisticated circles in Persia or in Anatolia but in simpler spheres and in sophisticated expression in Arabic, Persian, Turkish and Urdu. The Sufi orders acted as a bridge between the intellectualism of the high mystical reaches and the poetry of popular devotion.

The political role and ethics of the Sufi orders has been historically significant, and their impact profound. After the fall of Baghdad to the Mongols in 1258, they served to prevent the breakup of the Muslim world into Arabic, Turkish and Persian speaking regions. They had a 
stabilizing role in critical periods of change and political uncertainty. They became a significant element in establishing nations. We find leaders of orders aspiring to political power, revolting against established authority, and sometimes actually succeeding in founding a dynasty.

The most remarkable example of such a movement was that which led to the foundation of the Safavid dynasty in Persia. It was especially in the nineteenth century that the orders were in the forefront of Muslim reaction against the expansion of colonialist powers. This may be seen in the case of Indonesia, where the Tariqa Sammaniyya actively opposed the Dutch in Palembang in 1819 and in South Kalimantan in 1860. The Tariqa Qadiriyya wa Naqshbandiyya took part in the peasant's revolt of Banten in 1888 and in 1891 in Lombok against Hindu oppression in Bali. In West Sumatra, where there is also a strong Naqshbandi presence, strong resistance was shown in 1908 to Dutch presence by the Shattariyya order. In addition, the Sanusiyya in the late nineteenth century inspired the Achehnese war against the Dutch while its Shaykh in Libya was fighting against Italian incursions there from 1914 to 1918. In Indonesia, we may observe the establishment of a political party named Partai Politik Thariqat Islam (PPTI) in 1950 by Shaykh Jalal al-Din, a khalifa of Shaykh Ali Rida of Jabal Abu Qubais. He used to claim that the PPTI had been established as early as 1920, and that the initials then stood for Persatuan Pembela Thariqat Islam (Union of Defenders of the Islamic Tariqa). This organization seems to be attached to the Naqshbandi order and in the first Indonesian elections in 1955, a Sumatran Naqshbandi was elected to the national parliament as the sole representative of the tariqa political party (Lingwood 2014: 99).

The progress achieved by Sufism can be seen in the development of the tariqa, which consist of 3 levels:

1. The level of the khanqah (Sufi center), where the shaykh leads his disciples in their devotions. They perform spiritual exercises separately and collectively. At this stage, there is little specialization until the 10th century, at which point Sufism entered its golden age.

2. The stage of the tariqa, which occurred in the 13th century. At this stage the teachings, rules and methods had been developed. The silsila of each tariqa was declared and there was developed a new, collective method in spiritual exercise, Sufism reached the people of middle class. Nevertheless, it also started to decline at this stage.

3. The ta'ifa stage occurred in the 15th century. At that time the teachings and rules were being transmitted from the teacher to his disciples. The cult of shaykhs was a common feature, and at this stage, Sufism was catching on at the grass roots level (Lingwood 2014: 101).

The tariqas became great communities, comprising all strata of society, offering something to the educated and uneducated alike, tolerating a wide range of folk practices, yet preserving and extending a great tradition of spirituality. The khanqah offered lodging to travelers, medical treatment for the sick and help for the poor. For the period between the twelfth and nineteenth centuries it is hardly possible to write on any aspect of religion and society in the Islamic world without reference to the tariqas, yet it is precisely this period that has been most neglected by modern scholars (Lewis 2005: 9003-15). Until the beginning of the 20 th century the tariqas still played a great role in Islamic society, where the orientation to the life in the hereafter was very influential.

On the one hand Sufism may fulfill one's need for spiritual and moral values in the challenging times of today and the positive value given by tasawwuf maybe seen as a means toward educating a community as to its moral responsibilities. On the other hand, the imaginary aspect of Sufism might become a boomerang that would weaken the critical faculties of a Muslim, thus causing stagnation and setting back Muslims' progress. Even al-Ghazali 
explains that Sufi people are not interested in the knowledge of talimiyya that can be learned from books. They prefer mainly the knowledge gained through ilhamiyya and laduniyya. The knowledge of the ladunni is regarded as greater than that of the ta'limi (Al-Ghazali 2008: 140).

The late nineteenth and early twentieth centuries saw the orders attacked on all sides, but it was not this which made the difference from past time. Attackers had never been wanting; their beliefs had been refuted, their practices condemned, their dervishes ridiculed and occasionally executed, and their Shaykhs castigated. None of this abated their popularity to the slightest degree. What we have seen in our time has been a process of erosion set in motion through the twentieth-century spread of secularization, with consequent changes in the social order and the infiltration of secularist ideas. This process of change has so undermined the Sufi orders that in many parts of the Arab world in particular and other Islamic countries in general, they have declined (Trimingham 1998: 246).

Reform took the form of struggle against bid'a (innovations) and reinforcement of the Sunna. So it had been with Muhammad ibn Abd al-Wahhab, though this type of reform aroused the opposition of the 'ulama. Then towards the end of the century, the Salafi movement ascribed the stagnation of Muslim lands to the corruption of life through bid'a, and stressed that reformation could only come through the elimination of aberrations and a revivification of the Sunna (Arberry, 2008 13). The Salafi movement, associated with Muhammad 'Abduh and Rashid Rida, opposed nearly every aspect of the orders as degenerate and Sufism proper as un-Islamic, whilst tolerating the type of thought signified by the ethical teachings of al-Ghazali (Stoddart 2012: 16).

Attacks from fuqaha' and secular authority have been persistent, albeit intermittent, throughout the whole history of Sufism, though in practice a paralism of religious authority was admitted; but in the past these attacks had never done more than lead to the condemnation of individual Sufis and the suppression of particular orders. They never affected their position in the life of Muslim communities, since they ministered to a religious need and filled a gap in the expression of the deeper meaning of Islam. We have seen that the virtual disappearance of the orders in many lands by the middle of the twentieth century did not come through attack, either external or internal. It was the changing outlook that made the attacks of the critics, 'ulama', modernists, and new men, more effective and enabled them to enlist the aid of authority.

To begin with there was the spread of ideas of Islamic reform; return to the purity of primitive Islam, condemnation of innovations, and the struggle against superstitions became watchwords. The orders were particularly susceptible to this form of attack, for they have paid the penalty of institutionalization and especially of the adoption of the principle of heredity in holiness. Formerly, legal treatises had been taught together with Sufism in their establishments, but during the last hundred years those seeking Islamic learning had turned almost exclusively to centers such as the Azhar or Qarawiyyin. This broke the alliance between orthodoxy and Sufism, and meant that the content of studies became formal and unilluminated and that the orders lost the support of many of the fuqaha' class (Smith 1977: 56).

Others, influenced by new conceptions, who felt that Islam must be ready to relate itself to the new world into which they were being drawn, were even more opposed to the orders. Few objected outright to Sufim as an individual spiritual discipline on Ghazalian lines, even though they may have thought it a waste of time, but the form it had taken, its extravagant popular manifestations, was a different matter, and they held the orders responsible for the stagnation that had overtaken life in Muslim countries. They sought to discredit the shaykhs, not merely on this account, but also because they were particularist, limited, unenthusiastic about burning issues like nationalism, and were too attached to clan, family, and local traditions (Faudzinaim 2012: 21). 
The decline of Sufism has coincided with the decline of the Islamic religious sciences i.e., Islamic philosophy, theology, exegesis, and law. Today, opposed by the 'ulama', by the Salafitype of fundamentalist reformers, and by the secularized new men, and primarily undermined by changes taking place in the whole social and religious climate, the Sufi orders are in decline everywhere (Trimingham 1998: 250).

Rationalizing religion will lead to a formalized legalistic Islam, and will tend to narrow its religious aspects and moral values. An attitude that does not distinguish between halal (lawful) and haram (unlawful) has already become a style of life in the society. The development of modern thinking which emphasizes rational logic will decrease the sacred value and awareness of the existence of sin, which is sometimes full of temptation. Crime, drug addiction, corruption and violence, and the disappearance of moral values in the community are phenomena of the decline of this awareness. Hence we notice perhaps the appearance of counter culture which aims at re-actualizing the teachings of Sufism in modern life.

The appearance of young artists and poets among Indonesian Muslims who are paying more attention to the practice of Sufism has surprised an Australian professor, who sees it as an unusual phenomenon, since such enthusiasm, when allowed to develop without the reformation of the teaching of Sufism, might create khurafat, takhayyul and bid'a. That is why Prof. Hamka suggests that Sufism should return to the Quran and Sunna because this approach will help it adjust to the spirit of modern times. Others call for a reformation of Sufism to make it the third pillar of religion, which is ihsan. Ihsan means that "you worship God, as if you see Him, and when you do not see Him, indeed He sees you."

Sociologically speaking, we have seen religion displaced, or reduced from being the regulative principle behind life, sustaining and molding society, to become one among many aspects of social life, though receiving special recognition as a factor of differentiation within the universalism of secular culture. At the same time, Islam continues to be the guiding principle in the personal lives of vast numbers of people, and within Islam the Sufi tradition will continue to fulfill its mission of maintaining the deeper spiritual values through the special linkage and relationship with the spiritual world that the tariqa represents (Trimingham 1998: 258).

\section{Sufism as Element in Social Spiritualism and Political Ethics}

In modern Indonesia, Hamka, according to Nurcholish Madjid, is resposible for having promoted the notion of a new Sufism in Indonesia. He appreciates the role that it can play in the implementation of an esoteric Islam. It can dispense with the practice of 'uzlah while still being actively involved in society. Once in a while however the practice of 'uzlah could be recommended as a means of refreshing one's mind and as a starting point to perform more good deeds (Laffan 2011: 28).

According to Fazlur Rahman, Ibn Taymiyya and Ibn Qayyim al-Jawziyya, both classical figures, were the pioneers of neo-Sufism. Neo-Sufism is characterized by an emphasis on moral motive and the application the methods of dhikr and muraqaba or spiritual concentration on God (Fazlur Rahman 1979: 195). The objective and the context of concentration are the same as those in Salafi doctrine. The purpose is to strengthen belief in the true 'aqidah and assist in the moral purification of the soul. The phenomenon of neo-Sufism can contribute to the re-birth of salafi activities and a positive attitude towards the world (Fazlur Rahman 2000: 130). To some extent they admit the true claim of intellectual Sufism: they accept the kashf (experience of capturing God's truth) of the Sufis or their intuitive inspiration but reject Sufi claims of infallibility (ma'sum); indeed both Ibn Taymiyya and Ibn Qayyim al-Jawziyyah admitted that they had experienced kashf. The legitimacy of kashf is equal to moral cleanness and the purification of the heart to an unlimited degree. 
There is a Sufi element in 'Social Spiritualism' (al-Ruhaniyya al-Ijtima'iyya) as well, which features certain signs of spriritualism (ma'alim al-tariq):

1. Reciting and contemplating the meaning of the holy Quran.

2. Reciting and studying the meaning of prophet's presence through Sunna and his sira (biography).

3. Maintaining relationships with good people such as 'ulama' and Muslims who perform zuhd.

4. Keeping oneself away from bad attitudes and behaviour.

5. To study the soul and metaphysics as these are portrayed in the Quran and Sunna with a sense of iman (belief).

6. To perform obligatory worship and Sunna, five times a day, and tahajjud (Said Ramadan, 1992: 53-61).

In the Indonesian context, for example, one might consider the case of the tariqa Qadiriyya wa Naqshbandiyya, which through the efforts of its most dynamic branch in Suryalaya, has gained a lot of attention from the mass media for its system of curing young drug addicts. Abah Anom, the head of the tariqa's pesantren there, has developed a system for curing drug abusers through dhikr. This system was developed as a result of his belief in the practical experience of Sufi masters and the concept that dhikr Allah contains enlightenments, special characteristics and secrets which help to cure the hearts of Muslim believers. This belief is based on God's saying: "Remember me, I'll remember you. When you remember your God, the curtain of heedlessness will be removed from you, you will be the dhakir (and you) will be remembered, the one who is thankful (and you) will be thanked"(Geoffroy 2010: 122). Whatever the reason for the success and benefits of dhikr in Pesantren Suryalaya, the results are beyond question, as is demonstrated by the large numbers of those who have been cured of their dependency). Normally the healing process will take between 40 days and 6 months or more (Harun 1990: 410-411).

From the elements of the Sufi teachings and practices discussed in the above, we can perhaps see that the genuine nature of Sufi tradition is being maintained, and that this will never be lost. The Path, in our age as in the past, is for the few who are prepared to pay the price, but the vision of the few who, following the way of personal encounter and commitment, escape from Time to know re-creation, remains vital for the spiritual welfare of mankind (Trimingham 1998: 259).

As a conclusion, the emphasis of Sufism on individual piety results in personal satisfaction and fills a personal need for a link to the Creator as the Beloved. This attitude would be then furthered towards God's creatures as well, both human beings and nature. Therefore, individual piety should not be separated from social and environmental piety. Sufism solves difficulties in life by changing pessimism into optimism, worry into hope and hate into love. Only Sufism has the spiritual potential to avoid the absolutism that enslaves people. Perhaps those seeking to develop their religious life should turn more to Sufism, for in it lies the essence and the future of religion.

Sufism can still play a significant role as a tool of moral education, as well as in the field of psychiatry. This remains to be seen in many parts of the Islamic world, but the potential is always there. It is difficult to measure its success and yet at the same time is perhaps too early to say that it is in decline because the general trend in the Muslim world since the nineteenth century, in which people try to rationalize or secularize many aspects of human life and develop their nation for the sake of economic success and profit-making only, seems to ignore its importance. In fact, Sufism preserves the truly important aspects of life for human beings without rejecting the world. Sufism can be quite realistic without being materialistic. 


\section{References}

Arberry, A. J. 2008. Sufism: An Account of the Mystics of Islam. London: George Allen \& Unwin.

Dhofier, Zamakhshari. 1985. Tradisi Pesantren: Studi Tentang Pandangan Hidup Kiyai. Jakarta: LP3ES.

Dunn, R. E. 2012. The Adventures of Ibn Battuta: A Muslim Traveller of the 14th Century. Berkeley: University of California Press.

Faudzinaim Badaruddin. 2012. Peranan Kitab Jawi Tasawuf sebagai Medium Transmisi Ilmu Islam kepada Masyarakat Melayu Nusantara. International Journal of Islamic Thought 1: 19-26.

Fazlur Rahman. 1979. Islam. Chicago: The University of Chicago Press.

Fazlur Rahman. 2000. Revival and Reform in Islam: A Study of Islamic Fundamentalism. Oxford: Oneworld.

Geoffroy, É. 2010. Introduction to Sufism: The Inner Path of Islam. Indiana: World Wisdom.

al-Ghazali, Abu Hamid. 2008. Ihya 'Ulum al-Din. 5 vols. Beirut: Dar al-Khayr.

Gorman, M. 2010. Stairway to the Stars: Sufism, Gurdjieff and the Inner Tradition of Mankind. London: Aeon Books.

Laffan, M. F. 2011. Islamic Nationhood And Colonial Indonesia: The Umma Below the Winds. London and New York: Routledge Curzon.

Lewis, F. D. 2005. Tariqah, in Lindsay Jones. Encyclopedia of Religion. New York: Thomson Gale.

Lingwood, C. G. 2014. Politics, Poetry and Sufism in Medieval Iran. Leiden: E.J. Brill.

Muhammad Ali Aziz. 2011. Religion and Mysticism in Early Islam: Theology and Sufism in Yemen. London: I.B. Tauris.

Nasution, Harun. ed. 1990. Thoriqot Qodiriyah Naqsyabandiyah Sejarah, Asal-usul dan Perkembangannya. Tasikmalaya: Institut Agama Islam Latifah Mubarokiyah.

Rohaimi Rastam, et. al. 2015. Analisis Silsilah Tarekat Shaykh Shams al-Din al-Sumatra'i. International Journal of Islamic Thought. 8: 61-79.

Sa'id Ramadan. 1992. Al-Ruhaniyya al-Ijtima'iyya. Geneve: n.p.

Smith, W. C. 1977. Islam in Modern History. Princeton: Princeton University Press.

Stoddart, W. 2012. Outline of Sufism: The Essentials of Islamic Spirituality. Indiana: World Wisdom.

Trimingham, J. S. 1998. The Sufi Orders in Islam. New York: Oxford University Press.

Van Bruinessen, M. 1994. Shari'a Court, Tarekat and Pesantren: Religious Institutions in the Banten Sultanate. Archipel 47. 